\title{
KESADARAN POLITIK BERKETUHANAN SEBAGAI DASAR UNTUK MEWUJUDKAN KESEJAHTERAAN RAKYAT INDONESIA
}

\author{
Oleh: \\ Andri Azis Putra', Arqom Kuswanjono ${ }^{2}$, Misnar Munir ${ }^{3 *}$ \\ Program Doktor Filsafat Fakultas Filsafat, Universitas Gadjah Mada ${ }^{123}$ \\ andriazisputra@gmail.com ${ }^{1}$, \\ kuswanjono@ugm.ac.id ${ }^{2}$, \\ misnalmunir@ugm.ac.id ${ }^{3}$
}

\begin{abstract}
Welfare is one of the significant problems in human life. All aspects of human life politically will always be related, both as elements and indicators of welfare conditions. Consequently, the state is an organization and authority that can provide a measure and effectively regulate all efforts in the realization of people's welfare. However, practically "people's welfare" in Indonesia is still in a quarrel state with the targets-setting. This research is library research with a hermeneutic-philosophical approach. Political Theology, as a branch of the Philosophy of Religion, will be used as the primary approach by involving methodical elements that are balanced and consistent with research. Additionally, the involvement of other scientific disciplines such as political philosophy, social philosophy, and economics will enrich this research. This research shows that the efforts carried out to realize the welfare of the people is dominantly incompatible with the needs of the subjects receiving welfare facilities. The source of this problem is relying on the perspective of governmental values. New awareness and responsibility are needed to build a structure with a divine and human nature. This awareness arises as an implementation form of worship to God and also responsibility for that worship to fellow human beings..
\end{abstract}

Keywords: People's Welfare, Political Awareness, Religiosity, Political Theology

\section{A. PENDAHULUAN}

Kesejahteraan adalah salah satu persoalan paling mendasar bagi manusia dalam sebuah kehidupan komunal. Kesadaran mengenai kesejahteraan ini, secara langsung berhadap-hadapan dengan identitas sosial yang disandang seseorang. 
Setiap orang memiliki ide dan konsep tentang kesejahteraan, meskipun dalam tataran aktualisasi terdapat keragaman bentuk. Secara substansial manusia memiliki satu kesamaan yang disadari, yaitu tentang kesejahteraan, namun pada tataran bentuk terdapat keragaman dalam memaknai kesejahteaan itu sendiri.

Sebagai sesuatu yang mampu disadari secara bersama oleh manusia, kesejahteraan tetap menyisahkan persoalan. Terutama jika mengaitkan kesejahteraan sebagai sesuatu yang harus dipenuhi oleh organisasi masyarakat, seperti negara. Kesejahteraan merupakan sebuah ide yang subjektif secara mendasar, sehingga sulit jika dikembalikan kepada ide atau konsep yang universal. Meskipun demikian, menjadi sejahtera adalah cita-cita personal dan komunal dari seluruh manusia. Secara parsial, kesejahteraan menjadi sebuah keinginan mendasar dan cita-cita yang harus dicapai oleh rakyat di setiap negara, khususnya Indonesia. Sebagaimana yang terungkap di dalam preambule UUD 1945, memajukan kesejahteraan umum adalah salah satu tujuan di dalam bernegara. Sebuah dasar yang membuat posisi kesejahteraan semakin pantas untuk diteliti, dibahas, dan tentu saja untuk diwujudkan. Relasi langsung antara kesejahteraan dengan negara ini menjadikannya sebagai salah satu isu politik.

Sebagai sebuah isu politik yang bisa dikatakan terimplementasi secara masif pada kehidupan rakyat Indonesia, kesejahteraan tetap tak lepas dari persoalan kesenjangan.
Secara potensial kesejahteraan memutlakkan idealitas dalam praktiknya, sehingga secara mendasar dari segi ini terbuka celah ketidak optimalan pelaksanaan. Akan tetapi, di sisi lain seluruh rakyat Indonesia mengenal bahkan menyadari tentang kesejahteraan yang harus tuntas diberikan di dalam bentuk paling minimalnya. Sudut pandang yang digunakan oleh negara melalui pemerintah dan sudut pandang yang dipilih oleh masyarakat berbeda dengan jarak yang cukup jauh.

Dalam katalog Indikator Kesejahteraan Rakyat tahun 2019, terdapat tujuh poin utama yang dijadikan indikator kesejahteraan rakyat Indonesia. Penentuan dan evaluasi atas tujuh poin dari indikator ini adalah model yang digunakan oleh pemerintah. Secara detail, enam poin berkaitan dengan rakyat secara umum dan satu poin sebagai komparasi dengan negara-negara lain di ASEAN. Badan Pusat Statistik menekankan bahwa infrastruktur adalah penunjang terjadinya pembangunan yang baik dan penjamin terjadinya peningkatan kualitas kehidupan dan kesejahteraan manusia. Laporan ini juga menunjukkan bahwa infrastrtuktur yang menjamin kesejahteraan ini belum bisa secara maksial diadakan (Badan Pusat Statistik, 2019: 1-3).

Rakyat Indonesia sebagai
elemen paling penting dalam persoalan kesejahteraan dan sekaligus merupakan subjek yang sadar sepenuhnya terhadap dasar persoalan ini, terbelah menjadi beberapa jenis perspektif. Pembelahan perspektif ini terjadi disebabkan oleh fokus yang memang berbeda di kalangan 
masyarakat mengenai kesejahteraan. Secara ringkas bisa dikatakan bahwa perspektif masyarakat mengenai kesejahteraan tidak dalam bentuk integral sebagaimana yang dimiliki oleh negara. Secara mendasar perbedaan perspektif ini merupakan hal yang wajar karena rakyat pada dasarnya adalah kumpulan dari inividu-individu yang memiliki kemerdekaan dalam menentukan level minimum dari kebutuhan dan kepuasaannya. Sementara itu negara adalah kumpulan individu, konsep, dan rencana implementasi secara sekaligus.

Penelitian ini terfokus pada pertanyaan-pertanyaan inti, sebagai berikut, Apa tujuan dari ide kesejahteraan di dalam sebuah negara?, Apa peranan teologi politik dalam perihal kesejahteraan manusia?, dan Apa yang mungkin dimunculkan sebagai solusi para relasi teologi politik dan kesejahteraan rakyat di Indonesia?

\section{B. METODE PENELITIAN}

Penelitian ini adalah penelitian kepustakaan dengan menggunakan semua sumber yang relevan dengan topik penelitian. Filsafat Agama melalui Teologi Politik akan dijadikan sebagai pisau analisis utama beserta pendekatanpendekatan yang diperlukan. Sementara itu metode yang digunakan di dalam penelitian ini adalah metode hermeneutis-filosofis yang mencakup atas unsur-unsur metodis seperti: deskripsi, kesinambungan historis, induksideduksi, bahasa inklusif, dan heuristika. Penggunaan unsur-unsur metodis di atas bertujuan untuk menjamin penelitian agar terukur dan tertata dengan baik. Pisau-pisau analisis sekunder yang signifikan untuk dinyatakan adalah filsafat politik, filsafat sosial dan kajian kewarganegaraan.

Penelitian ini bertujuan untuk menemukan satu bentuk pemikiran asasi yang memungkinkan terjadinya relasi baik antara kesadaran politis, teologi dalam mewujudkan kesejahteraan rakyat di Indonesia. Untuk mencapai tujuan ini, beberapa langkah yang dibutuhkan di dalam keperluan penelitian kefilsafatan akan digunakan sebagaimana yang akan dijabarkan di dalam pembahasan mengenai metode penelitian. Langkah-langkah ini meliputi pengumpulan data, pengolahan data, dan kemudian pembuatan narasi.

Sebagai sebuah penelitian filsafat dan pemikiran, maka simulasi-simulasi yang bersifat naratif akan digunakan. Fungsi dari simulasi-simulasi ini adalah sebagai faktor penguat klaim atau gagasan serta sebagai salah satu teknis pembuktian secara logis atas ragam teori yang telah ada. Sementara itu pengutipan akan dilakukan dan digunakan dalam mendukung dan menunjukkan secara ilmiah keterpautan penelitian ini dengan penelitian-penelitian yang telah ada sebelumnya.

\section{HASIL DAN PEMBAHASAN}

Kesejahteraan rakyat adalah sesuatu yang tidak bisa dipisahkan sama sekali dari pembahasan mengenai negara. Negara yang berhasil dan dinilai maju akan memiliki indikator 
kesejahteraan rakyat yang baik. Peningkatan level kesejahteraan rakyat senantiasa berimbang dengan tingkat kebahagiaan komunal atau rata-rata bagi rakyat di suatu negara. Negara melalui seluruh kekuasaan dan alat-alatnya harus mewujudkan kesejahteraan rakyat. Proses yang dilakukan menuju ke arah kesejahteraan itu tentu saja tidak hanya melibatkan ha-hal ekonomis, namun juga politis. Jika menggunakan semua argumentasi yang telah dibahas pada bagian terdahulu, aspek politis justru mengambil porsi yang sangat besar di dalam sistem ekonomi negara. Dibutuhkan satu jenis kolaborasi antara ekonomi dan politik di dalam mencapai kesejahteraan bersama rakyat Indonesia. Nada sinis terhadap pengambil alihan yang dilakukan oleh orang-orang liberal tentu sangat mudah dimunculkan. Lalu benarkah bahwa ekonomi liberal atau neoliberallah yang mengambil paksa skema kesejahteraan Indonesia? Apakah rakyat dalam hal ini, termasuk pemerintah tidak menyadari bahwa dengan memberikan kekuasaan yang terlalu banyak kepada kaum kapitalis-liberal, hanya akan membawa ide kesejahteraan menjadi jauh dari cita-cita awal? Jika tidak, lalu apa sebetulnya yang paling mempengaruhi skema kesejahteraan rakyat di Indonesia?

Nurcholish Madjid meneropong hal ini dari dasar negara Republik Indonesia yang bermula dari poin Ketuhanan dan berujung pada poin Keadilan sosial. Pancasila adalah alarm yang senantiasa mengingatkan bahwa tujuan bernegara adalah untuk mewujudkan kemaslahatan bagi seluruh rakyat. Ketika terjadi ketimpangan di dalam kehidupan sosial masyarakat, ada orang-orang yang menarik keuntungan secara berlebih sehingga menghadirkan kerugian yang kentara pada banyak orang. Hal seperti ini tidak akan terjadi jika kesadaran untuk selalu mendahulukan kepentingan umum masih baik. Cak Nun menegaskan bahwa keadilan sosial tidak akan bisa dicapai jika praktik KKN masih belum tuntas untuk dihapuskan. Pemerintah harus menjernihkan kondisi ini dan memperhatikan dengan baik rakyat yang berada di dalam kondisi lemah. Keadilan sosial menurut Cak Nur hanya akan bisa dicapai ketika setiap orang di dalam suatu negara telah mendapatkan hal paling minimal yang dibutuhkannya sebagaimana yang juga dikenal dalam konsep welfare state (Madjid, 2004: 168-170).

Cak Nun, mengenai esensi kesejahteraan yang terkandung di dalam Pancasila, menegaskan bahwa peletakan Sila Ketuhanan Yang Maha Esa sebagai dasar bukan suatu ketidaksengajaan. Manusia Indonesia mesti memiliki keyakinan bersifat ilahiah sebagai basis seluruh kehidupan berbangsa dan bernegara. Dengan mengatakan sebagai basis bagi seluruh kehidupan, sebetulnya aspek Ketuhanan telah menetapkan standarisasi yang ideal orang Indonesia. Aspek paling mendasar ini kemudian disempurnakan oleh 3 sila selanjutnya dan ditutup oleh sila Keadilan sosial bagi seluruh rakyat Indonesia. Bisa dikatakan bahwa Ketuhanan adalah dasar dari seluruh pengembangan kemanusiaan, kenegaraan, kesepakatan, dan 
keadilan sosial di Indonesia. Dari sudut pandang ini jugalah kemudian Ketuhanan menjadi standar yang mesti dimengerti oleh setiap orang Indonesia. Tersangkutnya setiap individu di Indonesia dengan standar etika keilahian adalah sesuatu yang tidak bisa disangkal dengan cara apapun. Secara inheren, setiap manusia Indonesia harus memiliki kesadaran yang berketuhanan di dalam setiap pemikiran, sikap, dan perilakunya. Dalam relasinya dengan Pancasila, kesadaran berketuhanan harus digariskan secara lurus dan tepat menuju keadilan sosial seluruh rakyat Indonesia.

Agar dapat merumuskan lebih jelas mengenai Kesejahteraan Rakyat, pada bagian ini perlu diungkap setidaknya tiga aspek akhir sebelum masuk ke ranah implementatif. Tiga aspek penting ini pernah disampaikan oleh Mohammad Hatta mengenai kedaulatan rakyat. Tiga aspek ini berkaitan dengan sisi teologisteleologis dari ekonomi kerakyatan, keadilan politis, dan kesejahteraan di bawah naungan kesadaran yang berketuhanan. Dalam setiap kesempatan untuk menyampaikan ide-ide briliannya, Hatta sebetulnya tidak pernah meninggalkan pembahasan mengenai tiga aspek yang telah disebutkan ini. Ide mengenai ketuhanan, keadilan, dan kesejahteraan sosil bisa dikatakan sebagai tiga ide pokok yang selalu disampaikan oleh Hatta (Hatta, 2014: 50). Meskipun secara umum tulisan ini tidak memautkan kepada perspektif tertentu dari seorang tokoh. Akan tetapi pandangan kerakyatan yang diperkenalkan oleh Mohammad Hatta secara potensial bisa menjadi alur spirit utama di dalam tulisan ini. Tentu saja pilihan ini diambil bukan untuk menyangkal pemikiran kerakyatan jenis lain, namun untuk lebih mendekati pembahasan serta mengerucutkan pembahasan atas kondisi yang dibutuhkan.

1. Kesadaran Berketuhanan dan Target Kemakmuran Rakyat

Berketuhanan merupakan sebuah istilah yang paling tepat untuk menunjukkan posisi manusia dalam memiliki perpektif keilahian. Hal ini tidak memaklumkan kondisi seorang manusia yang mendapat ilham, penyingkapan, ataupun wahyu. Berketuhanan juga terasa lebih fair dalam mencari celah untuk menghukumi satu jenis kondisi mental yang dimiliki oleh manusia secara umum. Berketuhanan adalah memiliki kesadaran mengenai sistem yang dijalankan oleh Tuhan atau sistem yang dijalankan oleh sesuatu berdasarkan skema keilahian. Hal ini menjadikan kondisi berketuhanan menjadi jauh lebih luas jika dibandingkan dengan kondisi seorang manusia memiliki Tuhan yang disembahnya. Hal ini penting untuk diungkapkan karena pada dasarnya selalu ada keresahana yang muncul dari diri manusia ketika tidak memiliki dasar yang supranatural dalam tindakan-tindakanya. Bagi orang-orang yang mengakui dirinya sebagai ateis sekalipun, ada kebiasaan untuk menjalankan skemaskema dasar dari keyakinan.

Michael Novak mengungkapkan sebuah kondisi menarik yang terjadi pada ateis yang hidup di Amerika Serikat. Praktik yang dilakukan oleh 
para ateis Amerika dalam keseharian mereka, yaitu tetap melaksanakan kewajiban-kewajiban etis yang digariskan dalam agama Yudaisme dan Kristen. Bahkan para ateis ini dengan cukup bersungguh-sungguh mengusulkan dan menerapkan kewajiban-kewajiban dasar tersebut di tengah-tengah masyarakat. Para ateis ini tetap menyangkal keberadaan Tuhan namun tidak merasa terganggu dengan kewajibankewajiban yang merupakan ajaran yang berasal dari agama. Bagi sebagian orang yang memandang sekilas terhadap suatu fenomena, mungkin hal ini akan dinilai baik dan barangkali juga akan bangga. Akan tetapi jika ditilik dengan serius dan kritis, kondisi ini justru menunjukkan adanya hal yang mengkhawatirkan bagi para agamawan. Agama yang diyakini sebagai ajaran dari Tuhan tidak lagi dibutuhkan untuk dapat mendekatkkan diri kepada Tuhan. Bahwa Firman telah menjadi perbuatan di dalam pikiran manusia saat ini, sehingga persoalan kekuasaan manusiawi tidak lagi menjadi pertanyaan (Novak, 2018: 15-16).

Titik pijak paling penting yang disampaikan Novak adalah agama sudah menjadi sebuah rutinitas dan bagian dari pengembangan sosial kemasyarakatan. Secara klasik, ini bisa dianggap sebagai tindakan afirmatif terhadap ide agama. Namun, jika dibandingkan dengan apa yang dilakukan manusia di zaman ini, hal ini justru mengkhawatirkan. Seorang manusia tidak mesti mengakui dirinya beragama atau bertuhan untuk menjalankan standar moral yang baik. Begitu juga, seorang ateis bisa saja memberikan preskripsi mengenai standar-standar etis yang sebetulnya religius kepada masyarakat. Secara tidak langsung bisa dikatakan bahwa Tuhan bukan lagi pemegang kuasa satu-satunya di dalam kehidupan manusia. Sebagai contoh, pencapaian manusia di dalam ilmu pengetahuan tidak lagi dibatasi oleh keraguan mengenai kemampuan akan tetapi betul-betul murni jatuh kepada pilihan. Seorang ilmuwan bisa saja menciptakan sesuatu sebagaimana yang dibayangkannya, hanya dinding tipis moral saja yang kemudian menghalanginya. Sesuatu yang tentu saja sangat riskan jika mengingat apa yang pernah terjadi ketika Perang Dunia dahulu. Harga kehidupan dengan kondisi yang seperti ini akan berujung kepada negosiasi yang cenderung politis.

Poin kehidupan tentu saja menjadi sangat penting dan merupakan pokok pembahasan dalam kehidupan sosial politik jauh sebelum kemunculan teori-teori seperti bio-politik. Usaha untuk menyadari kehidupan sebagai sesuatu yang diberikan oleh Tuhan merupakan hal yang paling mendasar semenjak lama. Keberadaan manusia dengan adanya kesadaran semacam ini menunjukkan kebutuhan dan relasi yang tak terputus antara manusia dan Tuhan. Sementara itu orang-orang ateis melandaskan kehidupan kepada sesuatu selain Tuhan. Jika menggunakan pendekatan eksistensialisme, sebagai pendekatan yang paling masyhur di kalangan ateis maka akan ditemukan keyakinan terhadap hal-hal yang manusiawi. Tentu hal ini dengan muda bisa dimaklumi, mengingat salah satu persoalan atau isu terbesar 
di dalam keyakinan adalah mengenai penciptaan. Bagi kalangan ateisme, manusia mampu menciptakan nilainilai sehingga Tuhan tidak mesti ada dalam fungsi itu. Bagi kaum ateiseksistensialis, segala sesuatu akan berujung dan selalu berkaitan dengan kemampuan mencipta yang evolutif.

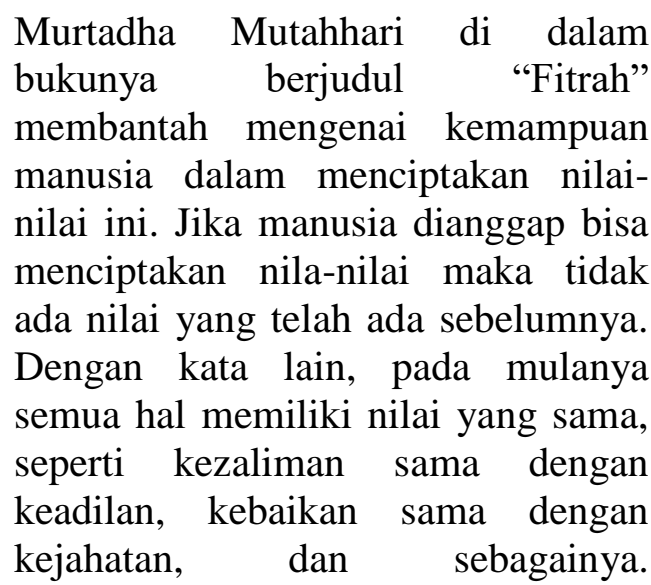
Selanjutnya Mutahhari menjelaskan bahwa hal yang mampu dibuat manusia tidak akan bisa melampaui dua hal, yaitu seni dan industri. Untuk mendapatkan penjelasan yang lebih baik, Mutahhari kemudian mengungkapkan bahwa apa yang dikenal dengan penciptaan nilai-nilai itu sebetulnya tidak lebih dari segala sesuatu yang dikenal sebagai anggapan. Seperti kepemimpinan yang diberikan kepada seseorang bermakna bahwa manusia bersepakat untuk menganggap ada sesuatu yang disebut kepemimpinan pada diri seseorang. Tanpa adanya anggapan tersebut, maka orang yang bersangkutan tetaplah orang yang sama dan tidak berubah. Begitu juga uang kertas yang sebetulnya hanya kertas biasa, akan tetap dianggap memiliki sesuatu yang bernilai (Mutahhari, 1998: 108-109).

Kesadaran manusia untuk mengenal Tuhan atau mengakui skema keilahian adalah salah satu cara yang mampu membuat manusia memiliki kesamaan visi. Untuk mendukung segala sesuatu yang dikembangkan dalam bentuk kerakyatan, kesamaan visi tentu saja merupakan hal yang baik. Jika kesadaran berketuhanan tidak dikembangkan di dalam diri seorang manusia, maka keberadan nilai menjadi sesuatu yang lebih rendah karena tercipta dalam sebagai anggapan manusia. Dalam logika ini, maka nilai akan bisa diganti dengan mudah. Secara praktis, tentu saja keberadaan nilai yang dengan mudahnya bisa diganti tidak akan membantu banyak. Manusia, membutuhkan sesuatu yang sulit atau mustahil untuk diganti karena keberadaannya yang lebih tinggi dari hal-hal jasmaniah tadi. Kesadaran sebetulnya tidak cocok disejajarkan dengan hal-hal yang bersifat materil. Kesadaran berketuhanan adalah sesuatu yang mampu membebankan tanggung jawab dan konsistensi bagi manusia dalam melihat satu tujuan jangka panjang yang berguna bagi banyak orang.

Kesadaran bersama ini sebetulnya bisa didapatkan melalui arahan yang legal dan sekaligus intitusional secara politis. Keberadaan dua aspek mendasar ini adalah untuk memastikan terpenuhinya kebebasan individual dalam perihal pencapaian kebahagiaan. Akan tetapi kebebasan individual yang juga membawa kebahagiaan ini harus berhenti di hadapan kepentingan bersama di tengah masyarakat. J.E. Rash dan Eric Waldbaum menyimpulkan melalui model demokrasi yang dikenal di Amerika Serikat bahwa kebebasan berekspresi berkaitan erat 
dengan tanggung jawab seorang warga negara. Lebih jauh Rash dan Waldbaum menegaskan bahwa kebebasan dan tangung jawab adalah persoalan keimanan yang paling tinggi (Rash, 2006:13).

Bagaimana cara untuk mengarahkan kesadaran berketuhanan ini menuju kemakmuran yang berdaulat bagi rakyat? Untuk mencapai pembahasan ini, apa yang dilakukan oleh orangorang ateis di Amerika menjadi contoh kasus yang unik. Jika nilainilai secara eksistensialis memang diakui sebagai sesuatu yang dibuat atau dihadirkan oleh manusia, maka semestinya ada beberapa kesepakatan yang berbeda dengan standar universal. Persoalannya adalah hal ini tentu saja akan sangat sulit untuk dikembangkan karena akan berhadapan dengan standar yang diakui oleh orang-orang non-ateis. Entah karena alasan praktis seperti ini atau dengan alasan-alasan yang lain, seperti ide inheren dan sejenisnya, kaum ateis akhirnya tetap menggunakan standar moral dasar sebagaimana yang dipahami secara universal oleh orang non-ateis atau umat beragama. Sebagaimana yang telah disampaikan sebelumnya, hal ini sebetulnya merupakan sesuatu yang mengkhawatirkan karena tentu saja nilai religius dan keilahian absen dari hal perilaku ini. Namun, di saat yang sama usaha yang dilakukan oleh orang-orang ateis ini menunjukkan afirmasi atas sesuatu yang tak terelakkan.

Dalam kamus keagamaan, kesesuaian yang bersifat universal dalam hal standar dasar dari moralitas tidak akan dipertanyakan karena jelas hal itu diyakini berasal dari Tuhan.
Skema bagi kaum religius adalah segala sesuatu berasal dari Tuhan dengan nilai-nilai unik yang melekat pada masing-masing hal. Jadi, Tuhan menciptakan segala hal dan sekaligus melekatkan nilai kepada masingmasing hal tersebut. Sehingga, manusia melalui perantaraan wahyu yang diturunkan kepada para Nabi, mengerti segala nilai tersebut. Persoalannya adalah nilai-nilai dasar ini telah dipahami dan digunakan oleh manusia semenjak dahulu kala. Bahkan jika melihat rentetan sejarahnya agama justru hadir lebih dahulu daripada ateisme. Meskipun cara bersikap terhadap Tuhan berubah secara drastis dalam pemikiran orang-orang ateis, akan tetapi dalam hal-hal yang bersifat manusiawi tidak terjadi banyak perubahan. Kaum ateis tentu saja menolak untuk menyatakan bahwa standar dasar moral adalah sesuatu yang diciptakan Tuhan, namun pertanyaan lain tentu akan menyusul, "Jika tidak dari Tuhan, lalu dari manakah standar tersebut?" Tentu saja membutuhkan waktu dan tingkat intelektualitas tertentu untuk menjawab pertanyaan ini. Beruntungnya, mayoritas dari orangorang ateis-eksistensialis memiliki kecerdasan yang bisa dinilai mumpuni sehingga dapat meyakinkan banyak orang yang berada di bawah level intelektualitas mereka. Meskipun demikian, adanya tren di dalam diri manusia untuk menyelesaikan satu tugas tertentu atau menyepakati nilai-nilai tertentu akan selalu membutuhkan jawaban yang tepat.

Sejarah filsafat klasik telah menunjukkan hubungan yang relevan 
dengan kondisi di atas. Garis historis yang paling jauh bisa ditarik hingga ke masa Anaxagoras ketika menyampaikan bagaimana struktur logis-rasional dari alam semesta terbentuk. Argumentasi yang disampaikan oleh Anaxagoras tentu saja masih sangat sederhana dan hanya tentang kait-kait general, jika dibandingkan dengan apa yang telah dimiliki oleh ilmu pengetahuan saat ini. Anaxagoras menyampaikan bahwa segala sesuatu berbentuk sangat banyak dan berserakan tanpa ada tujuan, hingga kemudian nous muncul dan semenjak itu terciptalah aturan. Argumentasi Anaxagoras ini kemudian secraa lebih rigid dikembangkan oleh para teolog seperti Thomas Aquinas. Aquinas menunjukkan bahwa segala sesuatu bertujuan untuk menyelesaikan satu pekerjaan dan pada akhirnya berujung pada kondisi yang paling baik. Kondisi ini menunjukkan bahwa segala sesuatu itu diarahkan oleh satu skema, dan bukan hanya berdasarkan kesempatan saja (Hudson, 1976: 56-57).

Dalam hal yang berkaitan dengan negara, pemikiran mengenai desain besar di atas berkaitan secara langsung dengan masa depan dari sebuah bangsa adalah tentang arah kehidupan yang dijalani secara bersama. Hal ini bisa diringkas dalam pertanyaan, "Kemanakah arah dari kehidupan komunal dari suatu bangsa?" Sebagai bahan perbandingan, jawaban yang akan muncul dari pertanyaan ini akan berkesusaian dengan bagaiamana satu bangsa memandang identitas kebangsaannya. Ketika rakyat yang hidup di negara yang dipimpinan secara totalitarian, jawaban mengenai arah kehidupan berbangsa akan diserahkan kepada pemimpin mereka. Sementara itu bagi masyarakat yang hidup di negara demokratis, tentu saja arah ini akan diserahkan kepada pembahasan di parlemen yang didasarkan kepada survey dari pandangan masyarakat banyak.

Pilihan apapun yang dipilih oleh suatu bangsa sebetulnya tidak menjadi persoalan, akan tetapi yang paling penting setiap manusia tentu akan menghindari kesalahan atau kesukaran dalam kehidupannya. Rakyat ketika menyerahkan arah kehidupan komunal bangsanya kepada pimpinan yang otoriter sebetulnya untuk menghindari kesukaran bagi dirinya. Begitu juga rakyat yang menyerahkan arah kehidupan komunal kepada para wakil rakyat juga untuk menghindari kesukaran hidup. Jika, seandainya setiap rakyat diberikan hak mutlak yang bisa membentuk arah komunal bagi bangsanya, tentu saja pilihan yang muncul adalah untuk menghindari kesukaran dan mendapatkan kenikmatan dalam hidup. Dasar inilah yang juga kemudian menentukan standar yang digunakan di dalam konsep negara kesejahteraan (welfare state). Tentang bagaimana sebuah negara mampu menghadirkan kenikmatan minimum bagi setiap rakyatnya. Sesuatu yang jika dikalkulasikan dengan baik dan adil akan menciptakan makna kemakmuran atau kesejahteraan.

Tentu saja, secara umum gagasan mengenai tercapainya standar kenikmatan atau kepuasaan minimum bagi setiap orang ini terdengar utopis. Terutama pada zaman ini, kondisi 
kepuasaan ini memang jarang ditemukan. Selalu ada satu atau orang orang atau bahkan satu, dua, tiga bahkan banyak kelompok yang tidak mendapatkan kepuasan minimum mereka. Sebuah pemandangan yang semestinya merupakan kemirisan paling mendalam di dalam kehidupan sebagai manusia akan tetapi telah dianggap biasa begitu saja. Pertanyaannya adalah apakah manusia di dalam sejarahnya pernah mengalami suatu jenis kesejahteraan atau kemamuran bersama? Atau dalam redaksinya yang lain, apakah manusa sama sekali tidak pernah berhasil menunaikan ide atau gagasan mengenai kesejahteraan bagi semua orang ini?

Sebagai bahan awal untuk menjawab dua pertanyaan di atas, ada baiknya melihat dari sudut ideal, yaitu agama. Abdul Qadir Audah pernah mengungkapkan mengenai standar ideal bagi sebuah negara sesuai dengan pandangan Islam. Negara yang baik adalah negara yang menjalankan prinsip-prinsip politik dalam ajaran Islam, seperti: mengakui persamaan, adil, merdeka, menjunjung rasa persaudaraan, menegaskan persatuan, memiliki semangat saling membantu, menegakkan hukum, membumikan budi pekerti, bijak dalam menggunakan anugerah Tuhan, tidak menimbum kekayaan, saling berbagi, dan mendahulukan musyawarah untuk mufakat. Sementara itu menurut Tahir Azhary, sesuai sunnah Nabi prinsip-prinsip negara Sebetulnya berasal dari sebaran ayatayat Al-Quran, seperti tentang kekuasaan sebagai amanah, kesejahteraan, persamaan, keadilan, dan Hak Asasi Manusia (SA \& Ilham, 2008: 31-32).

Keadilan sosial merupakan ujung dari cita-cita ilahiah Bangsa Indonesia. Pernyataan ini tentu saja menutup semua pintu yang memungkinkan untuk dimasuki oleh ateisme sebagai paham. Keyakinan tentang keberadaan Tuhan merupakan inti dari kehidupan Bangsa Indonesia. Notonagoro adalah seorang filsuf Pancasila yang memiliki pemikiran yang sangat runut atas hikmahhikmah di belakang Pancasila. Ia dikatakan sebagai peletak dasar pandangan bagi Pancasila secara filosofis dan dianggap sebagai dasar pandangan yang paling logis dan berkesuasian dengan cita-cita Negara Republik Indonesia. Sebagaimana yang dikutip dan dijabarkan ulang oleh Kaelan, Sila Ketuhanan Yang Maha Esa menjiwai dan mendasari keempat sila yang lainnya secara berurutan. Sila Ketuhanan Yang Maha Esa dianggap sebagai causa prima yang berarti penyebab atas segala sesuatu dan memiliki kekuasaan yang mutlak. Begitu juga Tuhan dalam relasinya dengan manusia berada pada titik yang paling tinggi, sehingg setiap kali manusia dibahas maka Tuhan juga turut dibahas. Poin inti dari hal ini adalah manusia merupakan akibat dari adanya Tuhan, atau dalam bahasa lainnya Tuhan adalah sebab dari keberadaan manusia (Kaelan, 2002: 161).

Perjalanan bangsa Indoensia bersama dengan Pancasila sebagai Dasar Negara dan Ideologi Bangsa tentu saja menghalangi pendekatan yang ateistis dan eksistensialistik. 
Keberadaan manusia di negara Indonesia adalah akibat dari keberadaan Tuhan dan keinginan Tuhan. Hal tentang keterlibatan Tuhan ini telah berkali-kali ditemukan di dalam sejarah pembuatan Dasar Negara dan Konstitusi Negara. Ateisme sebagai sesuatu yang personal bisa saja diterima keberadaannya di Indonesia sebagai wujud pelaksanaan HAM namun tidak boleh diterima sebagai alur gagasan. Dengan demikian, seluruh rakyat Indonesia mengakui bahwa Tuhan merupakan sebab bagi struktur moralitas berkemanusiaan, penetap persatuan, pembuat kesepakatan dan pemasti terjadinya keadilan sosial. Selanjutnya penerjemahan atas pernyataan ini secara regulatif adalah, negara harus menjadi penyambung tangan Tuhan untuk melaksanakan seluruh ketetapan yang secara potensial bisa diberikan oleh Tuhan dalam skala yang ideal. Pancasila merupkan standar legal bagi setiap usaha yang dilakukan oleh Negara Republik Indonesia dan sekaligus menyimpan amanah mengenai cita-cita Bangsa. Tentu tidak berlebihan jika dikatakan bahwa Pancasila adalah sesuatu dasar yang ditetapkan oleh manusia atas sebab yang lebih tinggi, yaitu Tuhan.

Keadilan sosial menjadi dalil yang tak bisa dibantah untuk menunjukkan keinginan bersama Bangsa Indonesia. Perlu untuk diingat kembali, bahwa munculnya lima sila sebagai dasar negara salah satu penyebabnya adalah keinginan untuk menghapuskan luka yang disebabkan oleh penjajahan. Bangsa Indonesia telah memerdekakan diri pada tanggal 17 Agustus 1945 dan langkah pertama yang dilakukan oleh para Bapak Bangsa adalah merumuskan Dasar Negara dan Konstitusi Negara. Dasar dari upaya yang dilakukan oleh para Bapak Bangsa ini tentu saja keinginan yang didapat dari keinginan rakyat. Maka penetapan akan adanya keadilan sosial bagi seluruh rakyat Indonesia tidak boleh dianulir, direduksi, atau dialihkan sebagai isu utopis. Tanggung jawab yang seharusnya muncul di dalam kepala setiap orang yang duduk di pemerintahan harusnya tentang bagaimana mewujudkan mimpi ini. Akan tetapi, catatan sejarah menunjukkan hal sebaliknya. Telah terjadi ketimpangan yang sangat besar, ketika regulasi dinilai tidak mampu menghadirkan keadilan sosial bagi seluruh rakyat Indonesia melalui rapat-rapat yang dilengkapi dengan fasilitas mewah. Terdapat banyak perkara etis yang lepas atau telah tanggal dari mentalitas politis orangorang yang dipercayai oleh rakyat ini. Alih-alih mengusahakan segala sesuatu yang mungkin bisa dilakukan, para politisi sibuk menolak bahwa kesejahteraan adalah sesuatu yang mungkin dihadirkan di negara ini.

Pernyataan ini barangkali dengan mudah dianggap sebagai sesuatu yang tendensius. Akan tetapi, idealitas yang melekat kepada Dasar Negara RI; Pancasila memang mengarahkan kepada penilaian semacam itu. Joko Siswanto mengungkapkan bahwa sistem ekonomi yang harus dilaksanakan di Indonesia harus berbasis kepada Pancasila. Dengan demikian, maka sistem Ekonomi Pancasila adalah sesuatu yang Hanya bisa dipahami 
oleh Bangsa Indonesia. Ketakutan adanya pernyataan yang tendensius hanya akan muncul jika sudut pandang yang digunakan dalam menilai Ekonomi Pancasila adalah perspekif ekonomi Barat. Siswanto lebih jauh mengungkapkan bahwa inti dari pengembangan ekonomi khas Indonesia adalah kemanusiaan, baik sebagai tujuan dari ekonomi maupun standar bagi sarana yang digunakan (Siswanto, 2015: 121122).

Ekonomi Pancasila barangkali adalah sistem yang ditemukan dan digunakan pada zaman Orde Baru. Seiring dengan mulai massifnya penggunaan konsep Demokari Pancasila. Akan tetapi, akar dari sistem Ekonomi Pancasila ini yaitu manusia, identik dengan akar dari sistem Ekonomi Kerakyatan yang terlebih dahulu dikampanyekan oleh Bung Hatta. Jenis sistem Ekonomi khas Indonesia, baik Ekonomi Pancasila maupun Ekonomi Kerakyatan adalah sesuatu yang dikembangkan untuk cocok dengan keperluan Bangsa Indonesia, dengan tingkat kemajemukan bangsa yang sangat tinggi. Secara mendasar, standar kepuasaan mimnimum yang dimiliki oleh Bangsa Indonesia beriringan positif dengan majemuknya kondisi Bangsa. Luasnya pembahasan mengenai kesejahteraan ini, kemudian harus diturunkan dalam bentuk dasar regulasi untuk kepentingan publik. Ide ini didasarkan kepada pemanusiaan yang harus terwujudu di dalam seluruh aspek kehidupan berbangsa dan bernegara.

Dalam persoalan kebijakan publik, tentu saja ada hal-hal yang harus diselesaikan di tingkat negara sebelum akhirnya dijadikan sebagai aturan. Sony Yuwono dan timnya menjelaskan bahwa salah satu penyebab dari mandeknya sebuah kebijakan adalah keengganan untuk berubah dan faktor ketidaktahuan. Sony menunjukkan bahwa ada kebiasaan untuk tidak mau berterus terang mengenai perubahan dan pengetahuan yang lebih baru. Akibatnya adalah penerapan new public management di dalam APBD sebagai contoh, sangat sulit untuk dilakukan. Keenganan untuk berubah dan mengakui ketidaktahuan terindikasi sebagai sebuah sikap atau perilaku yang bersifat bawaan dan bersifat kultural. Selain itu, tidak adanya kesepakatan awal sebelum membahas mengenai anggaran di tingkat legislatif juga memperparah kondisi. Hal ini menimbulkan pertanyaan bahwa apakah anggaran yang dibicarakan oleh anggota dewan diperuntukkan bagi rakyat atau bagi anggota DPRD itu sendiri? Seluruh kondisi ini menurut para profesional di bidang pembuatan regulasi berujung pda penempatan orangorang yang tidak sepenuhnya berkualifikasi baik dan sesuai dengan kebutuhan dari regulasi yang akan dibuat (Yuwono, Utomo, Zein, \& H. Azrafiany, 2008: 478-481).

Tambahan informasi dari tim yang telah bergelut dengan pembuatan anggaran dan regulasi ini menunjukkan bahwa proses yang berhubungan dengan pemajuan kesejahteraan rakyat tidak berjalan dengan baik. Jika dibawa ke ranah etis, tentu kondisi ini menggambarkan bahwa negara belum benar-benar serius dalam 
menyelesaikan persoalan mendasar Bangsa Indonesia. Bahwa, terdapat banyak persoalan yang harus diselesaikan atau dianggarkan juga merupakan hal-hal yang penting. Namun, apakah betul semua distraksi ini benar-benar menjadi alternatif yang baik dari ketiadaan jejak menuju sejahtera? Atau apakah kemajuan yang bersifat target gradual atau target progresif menuju kesejahteraan rakyat ini benar-benar diusahakan? Apakah rapat-rapat, gajigaji yang diberikan, pajak-pajak yang dipungut, dan segala macam hal lainnya itu benar-benar di dalam timbangan yang fair dengan penantian rakyat? Pertanyaanpertanyaan ini sangat penting untuk diajukan dan harus dijawab dengan kalkulasi yang masuk akal. Ketimpangan yang menyebabkan tidak meratanya angka kesejahteraan rakyat justru muncul dari hal-hal seperti ini. Sebagai contoh, ketika perdebatan mengenai harga beras sangat sulit untuk disepakati sementara itu rapat diadakan dengan makanan mewah. Ketika harga BBM dirasa begitu susah untuk direndahkan, akan tetapi rapat diadakan dengan cara menyeberang pulau. Tindakan-tindakan seperti ini adalah wujud ketidakpahaman dan ketidakmautahuan sekelompok orang yang dipercayakan untuk duduk sebagai pemerintah mengenai dasar kerakyatan di Indonesia.

Konsep-konsep yang telah disampaikan di atas, dimulai dari good governance, kesadaran bertuhan, skema holistik kesejahteraan di dalam Pancasila, dan ketidakmungkinan perubahan drastis atas kemakmuran rakyat menampakkan satu jalan baru yang cukup terang. Bahwa manusia Indonesia, harus kembali tunduk kepada Dasar Negara dalam nilainilai orisinil dan komprehensif di dalam Pancasila sehingga mampu melihat kebutuhan dasariah rakyat. Informasi mengenai adanya hambatan-hambatan mendasar di dalam pengembangan konsep Ekonomi Kerakyatan menjadi poin penting lainnya. Langkah penting yang harus dirumuskan setelah kembali kepada Dasar Negara adalah mengenai pendidikan karakter yang berkorelasi dengan kepatuhan atas amanah ilahi kepada seluruh manusia Indonesia. Kesadaran berketuhanan ini akan muncul satu semangat kerakyatan yang berdaulat. Dengan cara itu, kemajuan yang bersifat gradual akan bisa diusahakan melalui pemahaman-pemahaman yang baik dan peningkatan-peningkatan positif di dalam hal pembuatan regulasi yang memihak kepada kepuasan rakyat secara komunal.

Penemuan-penemuan yang telah disampaikan terkait dengan kemakmuran rakyat menunjukkan bahwa hampir seluruh sistem berada di dalam jalur politis. Pernyataan ini tentu saja secara langsung akan mengarahkan bagaimana kehidupan manusia, terutama dalam menjembatani ide di dalam negara Sebagai kehidupan yang bersifat politis. Dasar pandangan ini dengan mudah akan diarahkan oleh kelompok-kelompok tertentu sebagai afirmasi atas sekulerisme yang memang secara nyata terjadi. Secara metodologis, akan terdapat ketimpangan baru pada integralitas dari teori-teori yang mengandaikan 
adanya struktur tunggal pada aspek manusiawi dan ilahiah. Ketimpangan ini menjadi sangat mungkin terjadi jika meletakkan keyakinan ilahian sebagai salah satu dari alternatif model sistemik dari politik.

Muhammad Aziz Ahmed (1983) mengungkapkan bahwa kesalahan dalam memandang politik dan Islam terdapat pada usaha menyamakan antara Islam dengan teori-teori politik modern. Perilaku ini menurut Ahmed diperparah oleh sikap yang tidak konsisten oleh para ilmuwan Muslim dalam menjelaskan nilai-nilai dasar dari politik Islam. Di samping sebagai ajaran, Islam juga merupakan sistem nilai yang secara struktural mencakupi seluruh aspek kehidupan seorang manusia. Sudut pandang ini menjadi dasar untuk menolak dominasi hal-hal yang ritualistik di dalam Islam. Ahmed menyatakan bahwa melalui Al-Quran semua prinsip kehidupan manusia, baik secara umum maupun secara khusus telah disampaikan melalui Nabi. Islam di dalam pandangan Ahmed melalui penalaran khas dari Iqbal, bersifat integral dan influensial terhadap kehidupan manusia secara menyeluruh (Ahmed, 1983: 35-36).

Pernyataan yang disampaikan oleh Ahmed memang terfokus pada kondisi politik Islam. Akan tetapi bukan berarti kemudian, Islam menjadi satu-satunya agama yang potensial dalam memunculkan kesadaran berketuhanan di dalam aktivitas politik. Karena pada dasarnya, sekulerisme merupakan ide atau pemikiran yang membagi wilayah pembahasan dengan agama manapun. Islam, menjadi patron pada zaman ini dan seringkali dihadapkan secara frontal dengan sistem politik sekuler, karena Islam menjadi satusatunya agama yang masih mempertahankan status quo keagamaan. Apa yang diungkapkan oleh Ahmed di atas, pada dasarnya adalah fitrah dari kondisi mendasar dari seluruh agama terhadap kondisi politik.

Meskipun tidak dalam narasi yang terlalu positif, namun pandangan mengenai relasi Islam dan politik yang disampaikan oleh tokoh-tokoh Barat seperti Bertrand Russell perlu untuk diperhatikan. Russesll menyatakan bahwa keberhasilan Islam dalam melebarkan wilayahnya turut disebabkan oleh faktor politik yang mendukung Islam di masa itu. Islam melarang umatnya untuk menyakiti umat Nasrani, Yahudi dan kalangan-kalangan yang menyatakan beriman kepada Tuhan. Begitu juga Islam diuntungkan sekali oleh kondisi-kondisi manusiawi yang dihadapi oleh kalangan-kalangan minoritas di dalam agama lain, seperti penganut aliran Nestorian di wilayah Suriah, begitu juga kalangan penganut Monofisitisme di Mesir, bahkan umat Islam menerima kolaborasi bersama bangsa Berber yang cenderung tidak memiliki kondisi politik yang kuat (Russell, 2008: 297-298).

Penggambaran yang dilakukan Russell terhadap kebudayaan dan Islam menunjukkan bahwa posisi agama di dalam politik bukanlah sesuatu yang parsial atau terpecahpecah begitu saja. Akan tetapi, dalam bentuk aslinya, satu agama dengan agama lainnya tidak benar-benar berpisah sebagaimana yang dipikirkan oleh banyak orang. 
Kesadaran berketuhanan yang dimiliki oleh umat beragama sangat memungkinkan untuk mengalami persatuan di dalam aktivitas politis. Sesuatu yang memang tampak sama sekali berbeda jika sudut pandang yang digunakan adalah tradisi mainstream, seperti yang tampak dalam perang Salib. Seakan-akan agama Nasrani dan Islam sama sekali tidak bisa dipersatukan dalam satu model kondisi politik. Begitu juga jika sudut pandang yang digunakan adalah dalam melihat perperangan yang tak mengenal henti antara pihak Israel dan Palestina.

Bagi sebuah kondisi bernegara, sebetulnya kesadaran berketuhanan yang dikembangkan bukanlah bersifat parsial-destruktif. Sebagaimana yang terjadi dalam kerjasama Islam-Yahudi untuk mengalahkan kekuasaan Nasrani di Yerussalem, dan kaum-kaum minoritas kristen di Suriah dan Mesir dalam memuluskan penaklukan wilayah Islam, terdapat satu proyek yang politis-humanis dalam gerakan keagamaan. Sesuatu yang juga secara jelas memiliki akar ketuhanan di dalam pelaksanaannya melalui syarat-syarat ideal yang harus ditunaikan. Proyek politis-humanis inilah yang bisa dengan baik dianggap sebagai usaha menuju kemakmuran rakyat. Sesuatu yang hanya bisa dicapai dengan baik dan tepat di bawah kondisi berketuhanan dan bukan hanya bersifat politis ansich.

2. Keadilan Politik dan Usaha Implementatif pada konsep Kesejahteraan Bangsa
Sebagaimana yang telah ditemukan dan disampaikan sebelumnya bahwa pencapaian target secara dinamis dalam persoalan kemakmuran Bangsa, memerlukan satu kesadaran mendalam yang harus direkatkan kepada Tuhan Yang Maha Esa. Secara teologis dan politis, kondisi ini menjadi jaminan dan sekaligus sebagai pengingat bagi setiap orang mengenai asal muasal segala sesuatu. Ruang lingkup yang akan muncul dari jenis kesadaran berketuhanan ini mencakup semua hal, terutama persoalan tanggung jawab dan kekuasaan. Kalangan pemerintah, baik yang berada di jalur eksekutif maupun legislatif tentu saja membutuhkan jenis kesadaran ini untuk bisa benar-benar mengerti tentang lajur ilahiah yang dititipkan kepada negara. Pemahaman yang baik terhadap hal ini hanya akan bisa didapatkan dari pengetahuan yang tidak biasa. Maksudnya adalah pengetahuan yang berkenaan dengan hal ini benar-benar bersifat reflektifhistoris serta religius. Jaminan yang ingin didapatkan tentu saja diarahkan kepada kelurusan pandangan bahwa kesejahteraan Bangsa Indonesia diletakkan oleh Allah di dalam skema-Nya melalui tangan-tangan manusia terpilih. Penjelasan ini tentu berlaku di dalam tataran idea atau konsep awal yang mendasar bagi kesejahteraan. Lalu bagaimana dengan hal-hal yang bersifat konstitusional?

Inu Kencana Syafii (2020) mengungkapkan satu relasi unik yang sebenarnya dimiliki oleh kesadaran beragama dan kesadaran bernegara. Penjelasan ini dimulai dari analisis etimologis dari kata, "agama" yang 
terdiri dari "a" dan "gama". Secara literal pengertian a dan gama adalah tidak kacau. Syafii mengungkapkan bahwa ketika agama mengarahkan seksualitas sebagai sesuatu yang mengadung sifat kasih sayang dan menghindari timbulnya subjektivitas jenis kepemilikan individual, maka terciptalah pernikahan. Pernikahan yang diterima karena memiliki dua tujuan utama di atas, maka tidak boleh dilakukan terhadap keluarga inti dan pernikahan sesama jenis. Logika ini, bagi Syafii adalah pemasti nilai di dalam bentuknya yang lebih besar, abstrak dan rumit seperti dalam pemerintahan negara. Secara praktis, negara tidak dapat memperbolehkan dalam bentuk apapun hal-hal yang menyebabkan terjadinya subjektivitas kepemilikan personal dalam makna seksualitas, seperti praktik pelacuran dan tidak adanya pembatasan yang serius tentang hubungan seksual bebas di tempat-tempat wisata (Syafii, 2020: 39).

Pandangan yang disampaikan oleh Inu K. Syafii dianggap sesuatu yang cukup naif. Akan tetapi, di saat yang sama merupakan praktik-praktik yang hingga saat ini masih gagal diselesaikan oleh negara. Dikatakan gagal karena Negara sebetulnya tidak menerima semua hal itu secara konstiusional namun tidak mampu mendeliberasikan kesadarannya. Jika ditarik kesimpulan dari kondisi ini, sebetulnya skema politis yang tidak terapaut dengan kesadaran berketuhanan hanya akan melahirkan keputusan ambigu di dalam praktiknya.

Lalu bagaimana menghubungkan kesadaran berketuhanan ini dengan segala macam kebutuhan untuk memakmurkan rakyat? J. K. Lumunon, salah seorang tokoh Koperasi Indonesia menuliskan di dalam salah satu artikelnya bahwa ada tiga semangat yang diwariskan oleh Bung Hatta kepada Bangsa Indonesia. Tiga buah semangat ini merupakan prinsip-prinsip yang dibutuhkan oleh Bangsa Indonesia. Pertama adalah individualitas dengan makna harga diri dan kemandirian, kedua adalah solidaritas dengan makan kerja sama dalam gotong royong, dan yang ketiga adalah autoaktivita dengan makna hasil kerja bersama-sama yang menjadi respon logis dari keseluruhan proses. Dalam implementasi tiga semangat ini, Hatta menekankan pada inti semua persoalan, yaitu aspek manusia, yang memiliki semangat individualitas yang tinggi sebagai dasar keseluruhan proses (Lumunon, 2002: 314-316).

Aspek individualitas yang disampaikan Hatta sebagaimana dikutip Lumunon adalah kesadaran internal seorang manusia. Kesadaran tentang harga dirinya mengenai keyakinan atas kemandirian dan kemudian melahirkan semangat solidaritas untuk mencapai hasil yang baik. Tiga aspek semangat yang dibahas oleh Lumunon di atas disampaikan menggunakan bahasa koperasi sebagai wujud paling nyata dari ekonomi kerakyatan. Jika, individualita sebagai hal paling dasar mengibaratkan sebuah kesadaran yang berketuhanan, maka ekonomi yang berkesadaran ilahiah juga bisa ditemukan dalam aspek kemanusiaan yang baik. Hingga bagian ini, sistem ekonomi kerakyatan atau dalam bahasa Joko Siswanto sebelumnya yaitu Ekonomi Pancasila adalah 
pilihan yang paling dekat dengan sistem ekonomi berkesadaran ilahiah.

Pernyataan mengenai ekonomi kerakyatan ini bukan sesuatu yang berlebihan atau sebagai bualan saja. Dalam beban potensial yang dimiliki, terutama jika menghadapkan Ekonomi Kerakyatan dengan Ekonomi Liberal Kapitalisme, kesejahteraan bersama berpotensi lebih cepat tercapainya melalui skema ekonomi kerakyatan. Argumentasi terhadap klaim ini terdapat dalam model praktik yang telah dilaksanakan di Indonesia. Sebagai tandingan terhdap sistem ekonomi kerakyatan, muncullah satu kelompok elit ekonomi yang kemudian mengemudikan arah perekonomian Indonesia secara liberal pada zaman Orde Baru. Pengaruhnya adalah idea atau konsep dasar yang bersifat ideal di dalam sistem ekonomi apapun di Indonesia, tidak bisa diimplementasikan kecuali berhasil diselundupkan dengan susah payah ke dalam perencanaan yang konstitusional.

Pekerjaan yang berat demi mendapatkan keadilan politik-ekonoi ini pernah dilakukan oleh Mohammad Hatta ketika memaksa dan bersikukuh untuk tetap memasukkan dan mempertahankan pasal 33 dari UUD 1945. Meskipun kemudian paska-reformasi pasal ini menjadi salah satu pasal yang diamandemen, dengan hasil hilangnya kesaktian yang melekat pada koperasi. Akan tetapi, hal ini tidak merubah fakta bahwa perencanaan yang bersifat konstitusional adalah sesuatu yang berharga untuk dilakukan.
Sebagai pintu masuk menuju pembahasan yang siap guna dan impelementatif pada bab berikutnya, di dalam sub pembahasan ini akan dibahas mengenai posisi dari keadilan politik. Atau lebih tepat untuk dikatakan melalui pertanyaan, apakah relasi yang paling penting antara keadilan politik dan kesejahteraan Bangsa? Mengapa keadilan politik yang sangat konstitusioanl ini bisa menjadi jalan untuk mewujudkan kesejahteraan bangsa? Dua pertanyaan ini muncul sebetulnya dari praktik yang terlihat di dalam sistem demokrasi. Setiap orang memiliki satu kesempatan yang sama di dalam sistem demokrasi, sehingga seharusnya dimanfaatkan. Akan tetapi meski hal itu sudah dilakukan, bahkan dengan jumlah yang telah berhasil menutupi jumla mayoritas, kesejahteraan seakan-akan masih jauh dari kondisi terwujud.

Sebagai sebuah ide strategis dalam mewujudkan keadilan politik, individualitas yang disampaikan oleh Bung Hatta sebetulnya memiliki akar religius yang cukup kuat. Kesadaran seseorang mengenai apa yang dibutuhkannya dan menyadari mengenai metode untuk mendapatkan kebutuhan tersebut adalah proses awal datangnya kesejahteraan. Ada dua naluri pokok yang ada di dalam diri manusia, pertama hasrat seksualitas yang terwujud di dalam perkawinan, kedua hasrat kepemilikan benda baik properti, harta, dan juga ternak. Ibnu Khaldun pernah menyebutkan bahwa hasrathasrat yang ada di dalam diri manusia inilah yang menjadi penyebab utama timbulnya semangat untuk bekerja. Hasil dari pekerjaan manusia ini 
kemudian dikenal dengan nama rizki dan jika kemudian memiliki jumlah yang melebihi kebutuhan, akan dikenal dengan sebutan kasb (Mursyid \& Sani, 2016: 73).

Konsep kesejahteraan di dalam agama adalah menjadi seimbang. Kesejahteraan menjadi sesuatu yang inheren di dalam diri setiap manusia dan sekaligus menjadi penerpa komunitas secara eksternal. Secara personal, seluruh aktivitas yang dilakukan untuk mencapai kondisi sejahtera adalah sesuatu yang ditentukan secara timbal balik oleh subjek dan obyek, manusia. Sementara material-material lain termasuk di dalamnya pemikiran mengenai bentuk dan cara adalah tambahan yang memiliki sifat aksesoris. Dengan menyebutkan subjek dan objek yang berada pada satu entitas yang sama yaitu manusia, bisa dikatakan secara potensial segala usaha untuk mencapai kesejahteraan adalah hal yang bersifat internal kemanusiaan. Lebih spesifik dikatakan sebagai sesuatu yang muncul dari dalam diri manusia untuk kemudian ditangkap oleh manusia lain dan dimasukkan ke dalam dirinya juga. Sesuatu yang tidak mungkin muncul begitu saja dan tidak pula bisa dikatakan terjadi secara acak. Sebuah pengandaian yang secara langsung akan membuat pemikiran mengenai kesadaran muncul di dalam pilihan-pilihan menuju kesejahteraan ini.

3. Kesadaran Berketuhanan Sebagai Modal Perwujudan Kesejahteraan Rakyat Yang Berdaulat
Pada sub pembahasan yang terakhir ini akan dikemukakan dan ditegaskan kembali mengenai aspek kesadaran yang mesti dimiliki oleh seluruh rakyat. Meskipun masih bisa mendapatkan tempat dalam perdebatan mengenai kemestian terhadap kesadaran ini, akan tetapi hilangnya kesadaran yang baik; dalam hal ini kesadaran yang berketuhanan adalah salah satu pintu munculnya kesewenang-wenangan. Berdasarkan apa yang telah ditemukan dan dikembangkan dalam pembahasan sebelum ini, kesewenang-wenangan adalah bentuk politis yang sangat mempengaruhi kegiatan ekonomi bagi rakyat dalam mencapai kemakmuran atau kesejahteraan. Hampir bisa dipastikan bahwa para ahli dari dua disiplin ilmu besar ini akan sepakat dengan pernyataan bahwa ekonomi-politik dan politik-ekonomi benar-benar adalah hal yang sama. Kolaborasi yang dilakukan bisa dijelaskan dalam kajian-kajian yang meyakinkan. Akan tetapi, efek yang muncul di tengahtengah masyarakat hampir tidak bisa dibedakan. Akibatnya, struktur dari masing-masing baik ekonomi maupun politik secara bersama-sama akan mempengaruhi banyak hal di tengah masyarakat.

Jika politik dan ekonomi telah berhasil melakukan kolaborasi sedekat dan seketat itu, mengapa rakyat masih cukup jauh dari kondisi sejahtera? Pertanyaan ini barangkali sebuah pertanyaan klise dan sekaligus paling mudah untuk ditanyakan. Didik J. Rachbini (2001) mengungkapkan bahwa dalam praktiknya dimensi yang ada di dalam sistem ekonomi politik 
ditanggalkan dan diletakkan di bawah institusi pasar. Rachbini menyebut pola semacam ini dengan kapitalisme primitif yang lahir dari kolaborasi teknokral liberal dan pemerintah yang otoriter. Efek yang paling jelas bisa dilihat pada institusi-institusi nonpasar yang tidak mendapat perhatian sebagaimana mestinya. Menyampaikan tetesan ke bawah adalah satu skema klasik yang dikenal di dalam ekonomi, sehingga bisa tetap menghidupkan para pemaian kecil. Dengan kata lain, lapisan bawah dari ekonomi hanya mungkin hidup jika kelompok atas menyediakan secara khusus metode atau skema yang memungkinkan agar mereka mendapatkan pembagian. Secara teoritis, hal ini tentu saja merupakan pelanggaran terhadap sistem ekonomi politik sebuah negara (Rachbini, 2001: 2-3).

Konteks masa yang diangkat oleh Rachbini tentu saja sesuai dengan tahun terbit bukunya merupakan masa Orde Baru dan sebelumnya. Akan tetapi bahwa kesejahteraan belum juga didapatkan dengan baik oleh rakyat Indonesia, sehingga memungkinkan wacana yang disampaikan ini untuk tetap digunakan. Terutama sekali jika mengingat bahwa kebangkitan ekonomi yang terjadi bukanlah mengikut kepada standar kerakyatan akan tetapi lebih kepada sistem liberal. Salah satu bukti atas pernyataan ini adalah dengan terjadinya amandemen atau lebih tepatnya penghapusan tentang koperasi dari konstitusi Republik Indonesia.

Imamuddin Yuliadi (2001) menuliskan di dalam bukunya bahwa penyebab utama dari semua persoalan pembangunan dan ekonomi adalah sudut pandang materialistik manusia. Untuk lebih khusus, persoalan materialisme ini berhubungan dengan sudut pandang terhadap materi sebagai sesuatu yang bebas nilai. Sementara itu Islam seagai perwakilan agama secara komprehensif memutlakkan keberadaan tiga aspek utama yaitu tauhid, tanggung jawab dan keadilan. Eksistensi Tuhan dan pemberian tanggung jawab (taklif) yang mengharuskan timbulnya keadilan adalah satu rangkaian utuh. Jika ditarik lebih jauh, maka kesadaran bahwa Tuhan adalah satu-satunya yang berhak disembah menjadikan seluruh sistem dna kepentingan manusia akan dihadapkan kepada hal tersebut. Pemberian tanggung jawab kepada manusia oleh Tuhan dan kewajiban untuk selalu bertindak adil adalah bagian dari ibadah kepada Tuhan. Oleh karena itu setidaknya ada empat poin penting yang bisa dilakukan untuk menyusun strategi pembangunan di dalam Islam, yaitu: pengendalian terhadap permintaan yang berlebihan, pengembangan aspek motivasi dalam kehidupan manusia, pengembangan struktur ekonomi-sosial dan penegasan peran negara dalam pembangunan ekonomi masyarakat (Yuliadi, 2001: 200-202).

Masyarakat umum sebagai subyek yang menghendaki kesejahteraan tentu saja berhubungan dengan kebutuhan untuk mendapatkan akses yang terjangkau. Untuk menuntaskan kebutuhan ini seluruh penyedia fasilitas yang ada harus mengutamakan sudut pandang dari masyarakat. Sebab, pada dasarnya 
pemilik permintaan adalah penentu atas kebijakan yang akan dikeluarkan. Akan tetapi, di dalam praktik pemenuhan kebutuhan terdapat penetapan level atau tingkat yang berbeda-beda dan bisa dikatakan memiliki ketimpangan yang cukup tinggi. Di tengah masyarakat pemahaman mengenai pasar masih saja terbagi dengan tajam; yaitu antara pasar swalayan dan pasar tradisional. Bahwa adanya biaya tambahan sebagai kompensasi atas pelayanan yang berbeda model, tentu saja bisa diterima dengan baik. Akan tetapi, praktik pemenuhan kebutuhan ini tidak sesederhana mengenai graduasi level dan harga. Perbedaan kemudian mengikut kepada cara hidup, pilihan barang, dan tentu saja jenis perlakuan kepada penyedia kebutuhan, sesama subjek pemilih, dan ketersediaan barang yang kemudian terakumulasi dalam harga kebutuhan.

Perkembangan dan dinamika yang dilakukan untuk mencapai kesejahteraan perlu untuk diyakini sebagai sesuatu yang tidak baik secara penuh. Pernyataan ini dimaksudkan untuk menjelaskan segala sesuatu yang muncul secara praktis. Dukungan terhadap penerimaan adanya keburukan yang mungkin menyertai kebaikan di dalam sebuah proses ternyata adalah syarat penting untuk mendapatkan perkembangan spiritualitas yang sehat. Amin Abdullah (1996) pernah mengutip bahwa perkembangan spiritualitas manusia yang sehat ditandai dengan munculnya sikap fleksibelitas, rendah hati, dan keinginan internal. Sementara itu fitrah yang ada secara inheren di dalam diri manusia mengenai baik (taqwa) dan buruk (fujur) akan tetap ada, sehingga satu-satunya kemungkinan yang bisa dilakukan adalah melakukan penyeimbangan. Abdullah menegaskan bahwa tanpa adanya kedua fitrah itu, manusia akan sulit untuk dianggap dan disebut utuh. Bahkan tanggung jawab adalah sesuatu yang muncul sebagai muara dialektika antara komponen fujur dan taqwa. Secara maknawi, fujur dan taqwa dibutuhkan bagi pengalaman hidup yang baik dan bernilai. Sementara itu, penegasian yang sering dilakukan meskipun tanpa disadari adalah tindakan yang berpotensi merusak keseimbangan dari kehidupan dan kondisi spiritualitas manusia (Abdullah, 1996: 165-166).

Kesadaran yang ada dan dimiliki oleh manusia adalah aktivitas yang bersifat non-jasmaniah. Jika bisa diibaratkan sebagai sesuatu yang diproduksi oleh sesuatu, maka spiritualitas manusia juga akan selalu berkaitan dengan input dan media yang digunakan. Kesadaran dengan demikian, membutuhkan input-input yang cocok dan bisa memenuhi target luaran yang akan dicapai. Kesadaran mengenai adanya upaya untuk mencapai kesejahteraan tentu saja harus dipersiapkan melalui potensi input yang sesuai dan cocok. Dalam hal ini posisi input yang dibutuhkan untuk mendukung terjadinya kesejahteraan rakyat adalah sesuatu yang dekat dengan dua ide tersebut; rakyat da kesejahteraan. Sebagaimana yang telah dibahas sebelumnya, secara komunal kesejahteraan yang mungkin diwujudkan bersifat terbatas. Begitu pula, aspek 
kerakyatan harus dikondisikan dalam bentuk yang major dan tentu saja ini berlawanan dengan kebutuhan personal atau minor manusia. Hingga saat ini, nilai-nilai yang bisa mengatasi ide kesejahteraan dan ide kerakyatan dengan absolut hanya bisa ditemukan dalam ide Ketuhanan.

Sebagaimana halnya inspirasi yang dimungkinkan sebagai dasar atas pembangunan dan perkembangan Ekonomi Islam, tangung jawab memang harus memiliki sumber yang jelas. Yuliadi menyampaikan nilai utama di dalam penjelasannya mengenai Ekonomi Islam adalah ibadah kepada Tuhan. Dengan kata lain, ibadah menjadi pemasti nilai dan tanggung jawab adalah perintah yang memiliki dimensi ilahiah dan juga insaniah. Secara mendasar rasa tanggung jawab yang didasari oleh kesadaran bahwa seluruh kehidupan ini adalah bagian dari bakti diri kepada Tuhan akan menggiring pemikiran untuk membantu sesama manusia. Koneksi ini muncul sebagai respon terhadap rasa bertanggung jawab dalam pelaksanaan ibadah secara bersama-sama. Jika ditarik ke dalam areal pemerintahan maka akan berbunyi sama dengan kemampuan untuk berdaulat. Dalam istilah lainnya, sebuah rangkaian yang baik dan bertanggung jawab hanya akan mungkin muncul jika dipautkan kepada satu sumber yang bisa menggugah diri manusia. Kesadaran berketuhanan dengan demikian menerima kondisi ini dalam idenya yang komprehensif dan integral, terutama berkenaan kemestian yang terstruktur dengan baik.

Revrisond Baswir menuliskan bahwa kesalahan terbesar dari pemerintah
Indonesia secara historis salah satunya adalah melibatkan IMF. Pelibatan ini menurut Baswir sangat tidak menguntungkan bagi Bangsa Indonesia bahkan menimbulkan persoalan-persoalan baru seperti pendiktean atas kebijakan ekonomi Indonesia. Baswir lebih lanjut menunjukkan bahwa skema ekonomi secara mendasar akan membentuk watak manusia di dalam menyelesaikan persoalan ekonomis tersebut. Kesetiaan dan tanggung jawab yang berdasarkan konstitusi merupakan indikator yang paling baik bagi pembahasan ekonomi negara. Dalam praktiknya, rasa tanggung jawab yang setia dengan rakyat dna konstitusi ini memang akan merugikan banyak pihak yang terlalu menggandrungi ekonomi model liberal, atau sekarang neo-liberal. Baswir menyatakan bahwa satusatunya syarat yang harus dipenuhi demi terjadinya kondisi yang baik ini adalah adanya kemauan untuk bekerja keras agar terbebas dari perilaku dan keputusan ekonomi sebagaimana yang dirasakan saat ini (Baswir, 2003: 276-277).

Poin-poin yang berasal dari teori ekonomi non-religius yang disampaikan oleh Baswir di atas tentu saja menampakkan satu pola yang familiar dengan pembahasan dalam penelitian ini semenjak awal. Bahwa segala upaya yang dilakukan untuk mewujudkan kesejahteraan rakyat bukanlah sesuatu yang secara mendasar berhubungan dengan teoriteori ekonomi dan spekulasi di atas kertas. Akan tetapi secara lebih personal dan mendasar, upaya untuk mewujudkan kesejahteraan rakyat adalah hal yang besifat mentalitas 
dan dengan demikian maka akan berkaitan dengan kesehatan jiwa dari seluruh aktor perubahan. Secara teoritis, kondisi kesehatan jiwa dari seluruh aktor perubahan yang ada bisa saja didapatkan dari standarisasi yang bersifat positivistik atau dari hal yang bisa diukur. Namun, persoalan etis terutama di dalam nilai tanggung jawab hanya akan bisa didapat melalui dialektika internal yaitu dalam jiwa manusia. Kesadaran yang bertanggung jawab ini dalam relasi etis dan potensialnya merupakan kesadaran religius atau kesadaran yang berketuhanan.

Pelibatan tanggung jawab terhadap subjek penerima aksinya, meniscayakan untuk memiliki satu dasar yang bersifat komunal. Atas alasan pragmatisme dari segi nilainilai yang harus dipertahankan, maka syarat subjektif dalam aspek komunalisme ini bisa dimunculkan dari keberadaan rakyat dan tentu saja berhubungan dengan kedaulatan populis sehingga rangkaian kepentingan yang ada bisa terjaga dengan baik.

\section{KESIMPULAN}

Persoalan kesejahteraan berkaitan erat dengan identitas sosial seorang manusia sebagai sesuatu yang disadari dengan baik keberadannya. Bagi Bangsa Indonesia, kesejahteraan umum atau kesejahteraan rakyat adalah sesuatu yang harus dilaksanakan karena termaktub di dalam UUD 1945 sebagai kontitusi negara. Secara ringkas, kesejahterana rakyat Indonesia masih bersifat problematis karena adanya ketimpangan antara konsep dan praktik. Hal ini tampak dari laporan Badan Pusat Statistik mengenai pembangunan infrastruktur yang belum cukup jika disesuaikan dengan taraf yang ada. Pernyataan ini bersifat korelatif dengan tingkat kesejahteraan karena insfratruktur secara makro telah dijadikan sebagai indikator bagi pemasti kesejahteraan rakyat.

Secara mendasar penelitian ini menunjukkan bahwa unsur politis, ekonomis, dan religius berada di dalam satu wacana yang sama sebagai usaha untuk mewujudkan kesejahteraan rakyat, khususnya di Indonesia. Tidak ditemukan satu pernyataan atau teori, baik secara parsial maupun secara kolaboratif mengenai pentingnya kesejahteraan yang adil bagi seluruh rakyat. Akan tetapi usaha-usaha yang telah dilakukan selama ini masih saja terhambat oleh tindkaan-tindakan yang sebetulnya hanya menggunakan satu jenis pendekatan dan hal itu dilakukan secara memaksa. Wadah yang dilakukan dalam melakukan pemaksaan atas satu model ini tentu saja berada di dalam pemerintahan atau dalam bentuk lebih luasnya yaitu negara. Kondisi ini tentu saja menarik, karena ada usaha untuk lari dari kondisi asli dari rakyat Indonesia dan menggunakan sesuatu yang cenderung berbeda dengan kebutuhan rakyat Indonesia.

Pernyataan mengenai adanya pengembangan yang berbeda dengan kebutuhan komunal rakyat Indonesia secara argumentatif bisa dikaitkan dengan kecenderungan menggunakan sistem ekonomi liberal dengan ide materialisme sebagai dasar. Sementara itu dalam pengerjaan usaha-usaha secara mikro, kesadaran 
cenderung diturunkan standar pada batas yang diasumsikan bisa dilaksanakan dengan baik. Persoalannya adalah asumsi mengenai kebisaan perencanaan ini kemudian menjadi jenis utopis yang baru dan berkembang persis seperti itu terus. Model seperti ini tentu saja tidak sesuai dengan kebutuhan dan kepentingan universal manusia, sementara itu juga ada kesadaran bahwa sebetulnya dalam bentuk paling idealis sekalipun perencanaan yang dilakukan manusia masih saja tidak akan sempurna. Oleh karena itu, kemauan dan keinginan yang bijak berkesesuaian dengan kesadaran bahwa usaha untuk mencapai kesejahteraan dan kemakmuran

\section{Daftar Kepustakaan}

Abdullah, Amin, 1996, Studi Agama: Normativitas atau Historisitas?, Yogyakarta: Pustaka Pelajar.

Ahmed, M. A., 1983, Indikator Kesejahteraan Rakyat 2019. Jakarta: BPS RI.

Baswir, R., 2003, Di Bawah Ancaman IMF, Yogyakarta: Pustaka Pelajar.

Hatta, M., 2014, Demokrasi Kita, Bandung: Sega Arsy

Hudson, W. D., 1976, A Philosophical Approach to Religion, London: The Macmillan Press

Kaelan, 2002, Pendidikan Pancasila. Yogyakarta: Paradigma. bersama adalah sebuah sikap yang hanya muncul jika kesadaran yang dimiliki berkaitan secara koleratif dengan aspek-aspek keilahian.

\section{E. ACKNOWLEDGEMENT}

Beberapa bagian dari publikasi ini diambil dari naskah disertasi yang ditulis sebagai tugas penelitian akhir pada pendidikan Doktor Filsafat di Fakultas Filsafat, Universitas Gadjah Mada. Penelitian akhir ini mendapat bantuan dari dari Lembaga Pendidikan Lembaga Pengelola Dana Pendidikan (LPDP), Kementerian Keuangan RI melalui skema Beasiswa Untuk Dosen Indonesia Dalam Negeri (BUDI-DN).

Lumunon, J. K., 2002, Bung Hatta Mendidik Individualita, Solidarita dan Auto-Aktiva Dalam Berkoperasi, dalam Sri-Edi Swasono, Bung Hatta: Bapak Kedaulatan Rakyat (hlm. 305-312). Jakarta: Yayasan Hatta.

Madjid, N, 2004, Indonesia Kita. Jakarta: Universitas Paramadina.

Mursyid, A., \& Sani, A., 2016, Solusi Problematika Umat Dalam Perspektif Al-Quran, ElFurqania, 61-87.

Mutahhari, M., 1998, Fitrah. Jakarta: Lentera.

Novak, M.,2018, Teologi politik Radikal. Sleman: Penerbit Jalan Baru. 
Rachbini, D. J., 2001, Politik Ekonomi Baru Menuju Demokrasi Ekonomi, Jakarta: Grasindo.

Rash, J. E., 2006, Islam and Democracy: A Foundation for Ending Extremism and Preventing Conflict, Bedford: Legacy International

Russell, B., 2008, Bertuhan Tanpa Agama: Esai-esai Bertrand Russell tentang Agama, Filsafat dan Sains, Yogyakarta: Resist Book.

Syafii, I. K., 2020, Sejarah Pemerintahan (Sejarah Agama dan Sejarah Negara), Yogyakarta: Pustaka Pelajar.

SA, S., \& Ilham, M., 2008, Teori Politik Islam: Konsep, Gagasan dan Pengalaman
Historis Umat Islam Dalam Mengapresiasi Ajaran Islam Tentang Masyarakat dan Negara. Padang: Jurusan SKI Fak. Adab IAIN IB Padang.

Siswanto, Joko, 2015, Pancasila (Refleksi Kompherensif HalIhwal Pancasila), Yogyakarta: Lembaga Ladang Kata.

Yuliadi, I., 2001, Ekonomi Islam: Sebagai Pengantar, Yogyakarta: Lembaga Pengkajian dan pengamalan Islam (LPPI)

Yuwono, S., Utomo, D. C., Zein, H. S., \& H. Azrafiany, A., 2008, Memahami APBD dan Permasalahannya: Panduan Pengelolaan Keuangan Daerah. Malang: Bayumedia Publishing.. 